\title{
Helicobacter pylori anti-CagA antibodies: Prevalence in symptomatic and asymptomatic subjects in Turkey
}

\author{
M Fatih Abasiyanik MS ${ }^{1}$, Ersan Sander $\mathrm{MD}^{2}$, Barik A Salih PhD ${ }^{1}$
}

MF Abasiyanik, E Sander, BA Salih. Helicobacter pylori antiCagA antibodies: Prevalence in symptomatic and asymptomatic subjects in Turkey. Can J Gastroenterol 2002;16(8):527-532.

BACKGROUND: Several reports have shown the prevalence of anti-CagA antibodies to be associated with the development of peptic ulcer diseases, while others have indicated that there is no such association.

AIM: To examine the prevalence of antibodies to CagA and other Helicobacter pylori antigens in symptomatic and asymptomatic subjects in Turkey.

SUBJECTS AND METHODS: Sixty-six symptomatic subjects, 16 to 74 years of age, were examined for $H$ pylori by biopsy-based tests and ELISA. One hundred nineteen asymptomatic subjects, 20 to 65 years of age, were also tested serologically for the presence of $\mathrm{H}$ pylori. Samples from both groups that were found to be positive for $H$ pylori by ELISA were then tested by immunoblotting. RESULTS: Fifty-four (82\%) symptomatic subjects and 76 (64\%) asymptomatic subjects were found to be $H$ pylori-positive by ELISA. Samples from 30 symptomatic subjects who were found to be $H$ pylori-positive by ELISA were analyzed by immunoblotting. Antibodies to CagA $(116 \mathrm{kDa})$ antigen were detected in immunoblots of 11 of 14 (79\%) with chronic gastritis, 12 of 13 $(92 \%)$ with duodenal ulcer and three of three (100\%) with gastric cancer. Antigens of the following molecular weights were also detected in these 30 subjects: $89 \mathrm{kDa}$ (VacA) in $21(70 \%)$, $37 \mathrm{kDa}$ in $21(70 \%), 35 \mathrm{kDa}$ in $19(63 \%), 30 \mathrm{kDa}$ in $27(90 \%)$ and $19.5 \mathrm{kDa}$ in 19 (63\%). Immunoblots of 40 ELISA-positive asymptomatic subjects showed that $33(83 \%)$ had antibodies to CagA antigen, $26(65 \%)$ to VacA antigen, $30(75 \%)$ to a $37 \mathrm{kDa}$ antigen, $30(75 \%)$ to a $35 \mathrm{kDa}$ antigen, $39(98 \%)$ to a $30 \mathrm{kDa}$ antigen and $36(90 \%)$ to a $19.5 \mathrm{kDa}$ antigen.

CONCLUSIONS: Antibodies to CagA antigen were prevalent in both groups, regardless of the presence of gastroduodenal disease.

Key Words: CagA; Helicobacter pylori; Immunoblot; Peptic ulcer disease

Résumé à la page suivante

\footnotetext{
${ }^{1}$ Fatih University, Faculty of Science and Literature, Department of Biology/Microbiology Unit; ${ }^{2}$ Samatya Hospital, Gastroenterology Department/Endoscopy Unit, Istanbul, Turkey

Correspondence: Dr Barik Salih, Fatih University, Faculty of Science and Literature, Department of Biology/Microbiology Unit, Buyuk Cekmece, Istanbul, Turkey. Telephone +90-212-8890810, fax +90-212-8890832, e-mail basalih@fatih.edu.tr

Received for publication February 22, 2002. Accepted July 4, 2002
} 


\section{Anticorps anti-CagA d'Helicobacter pylori : prévalence chez des sujets turcs symptomatiques et asymptomatiques}

CONTEXTE : Plusieurs rapports ont fait état de la prévalence des anticorps anti-CagA associés au développement d'ulcères gastro-duodénaux, alors que d'autres nient l'existence d'un tel lien.

BUT : Étudier la prévalence des anticorps anti-CagA et de ceut dirigés contre d'autres antigènes d'Helicobacter pylori chez des sujets turcs symptomatiques et asymptomatiques.

SUJETS ET MÉTHODE : Soixante-six sujets symptomatiques âgés de 16 à 74 ans ont été soumis à des tests de dépistage de $H$. pylori au moyen du test ELISA et de biopsies. Cent dix-neuf sujets asymptomatiques de 20 à 65 ans ont aussi subi des tests sérologiques de dépistage sérologique de H. pylori. Des spécimens positifs à l'égard de H. pylori provenant des deux groupes, test ELISA à l'appui, ont ensuite été soumis à un test immunoblot.

RÉSULTATS : Cinquante-quatre (82\%) patients symptomatiques et
76 (64 \%) patients asymptomatiques se sont révélés $H$. pylori-positifs selon le test ELISA. Les spécimens de 30 sujets symptomatiques qui se sont révélés $H$ pylori-positifs ont été soumis au test immunoblot. Des anticorps anti-antigène CagA $(116 \mathrm{kDa})$ ont été décelés dans les immunoblots de 11 sujets sur 14 (79 \%) souffrant de gastrite chronique, de 12 sujets sur 13 (92\%) souffrant d'ulcère duodénal et des trois (100\%) sujets atteints d'un cancer de l'estomac. Les antigènes ayant les masses moléculaires suivantes ont aussi été détectés chez ces 30 sujets : $89 \mathrm{kDa}$ (VacA) chez 21 (70\%), $37 \mathrm{kDa}$ chez 21 (70\%), $35 \mathrm{kDa}$ chez 19 (63\%), $30 \mathrm{kDa}$ chez 27 (90 \%) et 19,5 kDa chez 19 (63\%). Les immunoblots de 40 sujets asymptomatiques $H$. pylori-positifs selon le test ELISA ont montré que $33(83 \%)$ présentaient des anticorps anti-antigène CagA, 26 (65\%) des anticorps anti-VacA, 30 (75\%) des anticorps dirigés contre un antigène de $37 \mathrm{kDa}, 30$ (75 \%) des anticorps dirigés contre un antigène de $35 \mathrm{kDa}, 39$ (98 \%) des anticorps dirigés contre un antigène de 30 kDa et 36 (90 \%) des anticorps dirigés contre un antigène de 19,5 kDa.

CONCLUSIONS : Les anticorps dirigés contre l'antigène CagA étaient prévalents dans les deux groupes, peu importe la présence de maladie gastroduodénale.
$H$ elicobacter pylori colonize the stomachs of approximately $50 \%$ of the world's population $(1,2)$. The prevalence of infection ranges from $25 \%$ in developed countries to more than $90 \%$ in developing countries $(2-5)$. In spite of this high prevalence, only a small percentage of infected individuals develop peptic ulcer disease (2), of which $H$ pylori plays an important role in the pathogenesis $(1,6-8)$. The cytotoxin-associated gene (cagA) and vacuolating cytotoxin gene (vacA) are among the important factors in the pathogenesis of peptic ulcer disease (1). These genes encode for CagA and VacA proteins, which stimulate antibody formation in infected patients $(2,6,9)$. The association of such antibodies with an increased risk of developing peptic ulcer diseases is controversial. Investigators from developed countries have found a significant association between the prevalence of CagA antibodies and duodenal ulcer (10-13). However, other studies, particularly those from developing countries, have shown no such association (4,14-19).

Several tests have been used to diagnose H pylori infection; these are divided into biopsy-based tests (CLO, culture, histology, polymerase chain reaction) and nonbiopsybased tests (serology, urea breath test) (20). Serological tests are noninvasive and are used to detect immunoglobulin (Ig) G, IgA and IgM antibodies in the sera of $\mathrm{H}$ pyloriinfected subjects. The ELISA test is the most widely used test for the detection of such antibodies in epidemiological studies $(4,21,22)$. Immunoblot assay enables the detection of antibodies against specified $\mathrm{H}$ pylori antigens, such as CagA and VacA antigens (21,23). The aim of the present study was to detect $H$ pylori antibodies in symptomatic and asymptomatic subjects by the ELISA test, and to determine the prevalence of anti-CagA antibodies and other $\mathrm{H}$ pylorispecific antigens in both groups by immunoblotting.

\section{SUBJECTS AND METHODS}

\section{Subjects}

Symptomatic subjects: Sixty-six patients attending the endoscopy unit at the Samatya Hospital, Istanbul, Turkey, from March to July 2000, with dyspepsia and abdominal pain as their main complaint, were selected randomly. The study group comprised 38 men and 28 women, 16 to 74 years of age (average age 45 years). All patients underwent endoscopy, and three biopsies were taken from the antral part of the stomach for CLO, culture and histology. A serum sample was obtained from each patient and stored at $-20^{\circ} \mathrm{C}$. Asymptomatic subjects: One hundred nineteen subjects (blood donors, school teachers and health workers), 20 to 65 years of age (average age 37 years), with no history of abdominal pain were selected randomly. A serum sample was obtained from each subject and stored at $-20^{\circ} \mathrm{C}$. A questionnaire was filled out for each subject.

\section{CLO test}

One biopsy was placed into the CLOtest (Clia Waived, USA) and kept at room temperature. The results were recorded as specified by the manufacturer.

\section{Culture}

Biopsies for culture were dissected into small pieces using a sterile blade and then inoculated onto Colombia agar medium (Oxoid, United Kingdom), with 5\% defibrinated sheep blood and selective supplements ( $H$ pylori-selective supplement, Oxoid). The cultures were incubated in anaerobic jars, in humidified, microaerophilic conditions, using CompyGen Gas pack (Oxoid) at $37^{\circ} \mathrm{C}$ for five days. The organisms were identified as $\mathrm{H}$ pylori by Gram staining, colony morphology, and urease, oxidase and catalase-positive reactions. 
Histology

Antral biopsies placed in $10 \%$ formalin were sent to the histopathology laboratory. Sections were stained with hematoxylin and eosin stain, and modified Giemsa stain, and examined by an experienced histopathologist.

\section{Enzyme immunoassay}

The ELISA-kit SIA-H pylori (Sigma, USA) was used to detect IgG antibodies to $H$ pylori in human sera. The test was conducted according to the manufacturer's instructions. Samples were washed with the EL $\times 50$ Auto Strip Washer, and the results were read with the $E L \times 800$ Universal Microplate Reader (Bio-Tek Inc, USA). All samples were tested at the same time.

\section{Immunoblot assay}

The Helico-Blot 2.1 (Genelabs Diagnostics, Singapore) was used to test the ELISA-positive serum samples from both groups. The test is based on Western blot assay of $\mathrm{H}$ pylori whole-cell antigens that is made from bacterial lysate of a strain of $H$ pylori that is known to cause ulcers. Strips were marked at the $116(\mathrm{CagA}), 89(\mathrm{Vac} A), 37,35,30$ and $19.5 \mathrm{kDa}$ antigen lines and at an additional antigen line, designated the current infection marker (CIM). The recommended criteria for determining $\mathrm{H}$ pylori seropositivity as specified by the manufacturer is any one of:

- the detection of $116 \mathrm{kDa}(\mathrm{CagA})$ band with one or more bands of 89, 37, 35, 30 (UreA) and $19.5 \mathrm{kDa}$ together, or with CIM;

- any one band of the 89,37 or $35 \mathrm{kDa}$, with or without the CIM; or

- detection of both the 30 and $19.5 \mathrm{kDa}$ bands, with or without the CIM.

Imaging and analysis of immunoblots were done using Gel Doc 2000 and Quantity One quantification software (BioRad, USA).

Statistical analysis

Data were analyzed using SPSS 10.1 (SPSS Inc, USA). $\mathrm{P}<0.05$ was considered to be statistically significant.
TABLE 1

Correlation between the presence of Helicobacter pylori anti-CagA antibodies, detected by immunoblotting, and age in symptomatic subjects who were found to be $H$ pylori-positive by biopsy-based tests

\begin{tabular}{lc}
\hline Age (years) & $\begin{array}{c}\text { CagA+ } \\
\text { subjects, } \mathbf{n}(\%)\end{array}$ \\
\hline$>45(n=14)$ & $12(86)$ \\
$<45(n=16)$ & $12(75)$ \\
Total $(n=30)$ & $24(80)$ \\
\hline$P>0.05$ &
\end{tabular}

Symptomatic subjects

Biopsies were taken, and the presence of $\mathrm{H}$ pylori was determined through CLO, culture and histology. Patients were considered to be infected if one test was positive. Fiftyseven of 66 patients were found, by either one of the biopsybased tests, to be infected with $H$ pylori. Results of the ELISA test were compared with those of the biopsy-based tests. ELISA was shown to have $89 \%$ sensitivity (95\% CI 81.5 to $95.5 \%), 100 \%$ specificity, $100 \%$ positive predictive value and $67 \%$ negative predictive value $(95 \%$ CI 55.5 to $78.3 \%)$. Among the 66 symptomatic subjects included in the study, 32 of 38 (84\%) men and 22 of 28 (79\%) women were found to be $H$ pylori-positive by ELISA - a total of 54 of $66(82 \%)$ subjects.

Immunoblot assay was performed on 30 randomly selected ELISA-positive sera from symptomatic subjects. Table 1 shows the correlation between the prevalence of CagA antibodies and age. Twelve of 14 (86\%) patients older than 45 years of age and 12 of $16(75 \%)$ patients younger than 45 years of age were positive for CagA antibodies. Statistical analysis showed no significant difference between these age groups. CagA antibodies were detected in patients with the following histological findings: 11 of 14 (79\%) with chronic gastritis, 12 of 13 (92\%) with duodenal ulcer and three of three (100\%) with gastric cancer (one patient also had gastric ulcer) (Table 2). VacA antibodies

\section{TABLE 2}

Prevalence of antibodies to Helicobacter pylori antigens in immunoblots of symptomatic subjects with peptic ulcer diseases

Molecular weight of antigens (kDa)

\begin{tabular}{lcccccc} 
Subject group & $\mathbf{1 1 6}(\mathrm{CagA})$ & $\mathbf{8 9}(\mathrm{VacA})$ & $\mathbf{3 7}$ & $\mathbf{3 5}$ & $\mathbf{3 0}$ & $\mathbf{1 9 . 5}$ \\
\hline Gastritis, $\mathrm{n}=14(\%)$ & $11(79)$ & $8(57)$ & $9(64)$ & $9(64)$ & $11(79)$ & $7(50)$ \\
Duodenal ulcer, $\mathrm{n}=13(\%)$ & $12(92)$ & $11(85)$ & $10(77)$ & $8(62)$ & $13(100)$ & $10(77)$ \\
Gastric cancer, $\mathrm{n}=3(\%)$ & $3(100)$ & $2(67)$ & $2(67)$ & $2(67)$ & $3(100)$ & $2(67)$ \\
\hline
\end{tabular}


TABLE 3

Prevalence of antibodies to Helicobacter pylori antigens in immunoblots of symptomatic and asymptomatic subjects

\begin{tabular}{lcccccc}
\hline & \multicolumn{5}{c}{ Molecular weight of antigens (kDa) } \\
Subject group & $\mathbf{1 1 6}(\mathbf{C a g A})$ & $\mathbf{8 9}($ VacA) & $\mathbf{3 7}$ & $\mathbf{3 5}$ & $\mathbf{3 0}$ & $\mathbf{1 9 . 5}$ \\
\hline Symptomatic, $\mathrm{n}=30(\%)$ & $26(87)$ & $21(70)$ & $21(70)$ & $19(63)$ & $27(90)$ & $19(63)$ \\
Asymptomatic, $\mathrm{n}=40(\%)$ & $33(83)$ & $26(65)$ & $30(75)$ & $30(75)$ & $39(98)$ & $32(80)$ \\
\hline
\end{tabular}

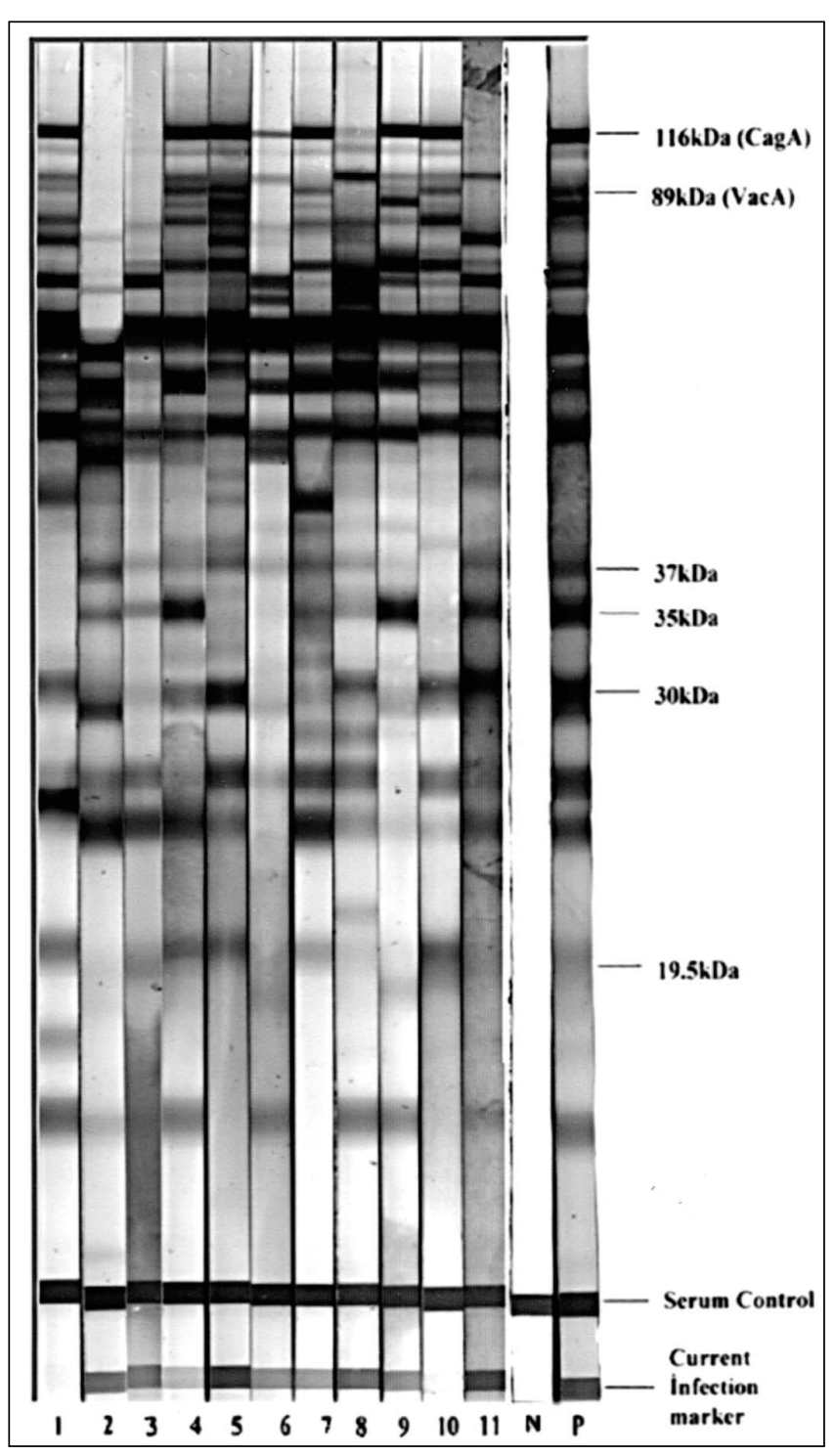

Figure 1) Representative immunoblot strips from Helicobacter pylori-positive asymptomatic subjects. N Negative control (normal human serum negative for antibodies to $\mathrm{H}$ pylori); $P$ Positive control (inactivated human serum with immunoglobulin $G$ antibodies to H pylori)

were detected in eight of 14 (57\%) subjects with chronic gastritis, 11 of $13(85 \%)$ with duodenal ulcer and two of three $(67 \%)$ with gastric cancer. Antibodies to the other four antigens varied also in their frequency pattern (Table 2). The CIM appeared in 25 of 30 (83\%) positive strips.
Asymptomatic subjects

Among the 119 asymptomatic subjects, 76 (64\%) were found to be $H$ pylori positive by ELISA. The sera from 40 of these subjects (randomly selected) were analyzed by immunoblotting. Table 3 compares the immunoblot results of $H$ pylori antigens in symptomatic and asymptomatic subjects. Immunoblots revealed antibodies to CagA antigen in $26(87 \%)$ symptomatic and $33(83 \%)$ asymptomatic subjects. The frequencies of immunoreactive bands to VacA and to other antigens in the immunoblots of both groups were variable. The CIM was detected in 35 of 40 (87\%) positive strips. Figure 1 shows representative immunoblot strips from $H$ pylori-positive, asymptomatic subjects.

\section{DISCUSSION}

In this study, the prevalence of $\mathrm{H}$ pylori in gastric biopsies of symptomatic subjects was determined by CLO, culture and histology. If one test was positive, patients were considered to be infected. Others have reported using a similar approach (18). In comparison with the biopsy-based tests, serology proved to be useful for the detection of $\mathrm{H}$ pylori infection (24). A review of the overall performance of the commercially available serology kits that measure IgG antibodies showed that serology is an accurate method of diagnosing $H$ pylori in patients (25). Comparison between serology and the combination of CLO, histology and culture revealed $94 \%$ sensitivity and $88 \%$ specificity (18). Compared with the biopsy-based tests, ELISA was $89 \%$ sensitive and $100 \%$ specific in detecting $H$ pylori infection in symptomatic subjects. These results were in agreement with those of an earlier study (25).

$\mathrm{H}$ pylori is associated with several gastroduodenal diseases such as gastritis, gastric ulcer, duodenal ulcer, gastric adenocarcinoma and mucosa-associated lymphoid tissue (MALT) lymphoma $(2,26,27)$. CagA has been associated with the development of peptic ulcer disease and gastric cancer. It is expressed in approximately $60 \%$ of the isolates and the protein is highly immunogenic (4), while vacA gene, although present in nearly all strains, is expressed in only $50 \%$ of the isolates (18).

Immunoblotting is a more sensitive serological test than ELISA for the diagnosis of $H$ pylori infection and the detection of specified antigens $(6,15,19)$. With immunoblot testing, no significant age difference in the response to CagA antigen between patients older than 45 years and those younger than 45 years of age was found, indicating that the prevalence of CagA-positive strains is not restricted to 
older age and that subjects in different age groups mount a good antibody response to the CagA antigen.

An increase in the prevalence of anti-CagA antibodies has been reported in patients with peptic ulcer disease and those with gastric cancer $(2,4,20,28)$. There appears to be major geographic differences in the prevalence of CagApositive strains. In Australia, the prevalence of antibodies to CagA in patients with duodenal ulcer was higher than that in those with nonulcer dyspepsia and in asymptomatic people, while in China, no significant difference in the prevalence of CagA antibodies between asymptomatic and gastric cancer groups was found (4). In another study, host and environmental factors were found to be more important in the development of the disease (29). In the present study, the detection of such antibodies in the sera of symptomatic and asymptomatic subjects indicates that CagApositive $H$ pylori strains prevailed in both groups. These results appeared to be in agreement with those of previously published reports $(4,15-17,27,30)$. Rocha et al $(23)$ indicated that immunoblotting using the Helico-Blot kit is useful for the diagnosis of $\mathrm{H}$ pylori infection in children and that the frequency of immunoreactive bands to $\mathrm{Cag} \mathrm{A}$ antigen is higher in children with duodenal ulcer than in children without the disease. However, Mitchell et al (31) reported in an earlier study that antibody to CagA is not a marker for specific disease in children. More recently, Figueiredo et al (24) compared the Helico-Blot kit with two other noncommercially developed enzyme immunoassays and concluded that the detection of anti-CagA antibodies

\section{REFERENCES}

1. Dunn ED, Cohen H, Blaser MJ. Helicobacter pylori. Clin Microbiol Rev 1997;10:720-41.

2. Kimmel B, Bosserhoff A, Frank R, Gross R, Goebel W, Beier D. Identification of immunodominant antigens from Helicobacter pylori and evaluation of their reactivities with sera from patients with different gastroduodenal pathologies. Infect Immun 2000;68:915-20.

3. Vaira D, Malfertheiner P, Megraud F, et al. Diagnosis of Helicobacter pylori infection with a new non-invasive antigen-based assay. HpSA European Study Group. Lancet 1999;354:30-3.

4. Mitchell HM, Hazell SL, Li YY, Hu PJ. Serological response to specific Helicobacter pylori antigens: Antibody against CagA antigen is not predictive of gastric cancer in a developing country. Am J Gastroenterol 1996;91:1785-9.

5. van Doorn L-J, Henskens Y, Nouhan N, et al. The efficacy of laboratory diagnosis of Helicobacter pylori infections in gastric biopsy specimens is related to bacterial density and vacA, cagA and ice $\mathrm{A}$ genotypes. J Clin Microbiol 2000;38:13-7.

6. Park MS, Hong S, Jung HY, et al. Antigenic diversity and serotypes of Helicobacter pylori associated with peptic ulcer diseases. Korean J Intern Med 1998;13:104-9.

7. Zevering Y, Jacob L. Naturally acquired human immune responses against Helicobacter pylori and implications for vaccine development. Gut 1999;45:465-74.

8. Rudi J, Kolb C, Maiwald M, et al. Diversity of Helicobacter pylori vacA and cagA genes and relationship to $\operatorname{Vac} \mathrm{A}$ and $\mathrm{Cag} \mathrm{A}$ protein expression, cytotoxin production, and associated diseases. J Clin Microbial 1998;36:944-8.

9. Censini S, Lange C, Xiang Z, et al. cag, a pathogenicity island of Helicobacter pylori, encodes type I-specific and disease-associated virulence factors. Proc Natl Acad Sci USA 1996;93:14648-53.

10. Ando T, Perez-Perez G, Kusugami K, Ohsuga M, Block KC, Blaser MJ. Anti-CagA Immunoglobulin $\mathrm{G}$ responses correlate with interleukin-8 induction in human gastric mucosal biopsy culture. Clin Diagn Lab Immunol 2000;7:803-9. is strongly dependent on the test used. The limitations reported by Figueiredo et al (24) in their interpretation of the results were due to several factors that included observer visual scoring, low intensity of some signals and variation between different strip batches that prevent accurate alignment. These limitations were overcome in our study by the use of Gel Doc and the Quantity One software program for imaging and analysis.

Differences in the frequencies of the immunoreactive bands to the six antigens between the symptomatic and asymptomatic subjects in the present study were attributed to individual and strain variability. In addition, the human gastric mucosa colonized by $\mathrm{H}$ pylori shows a variety of responses that may vary greatly in the intensity and distribution of the histological responses and correlation with the clinical outcome (11). The detection of CIM did not seem to add any further information to the interpretation of the results.

\section{CONCLUSIONS}

Antibodies to CagA antigen are prevalent in both symptomatic and asymptomatic subjects, regardless of the gastroduodenal disease. This gene product might be insufficient to act as a marker for the development of the disease in some populations.

ACKNOWLEDGEMENTS: The authors thank Meral Tunc for her technical assistance.
11. Navaglia F, Basso D, Piva MG, et al. Helicobacter pylori cytotoxic genotype is associated with peptic ulcer and influences serology. Am J Gastroenterol 1998;93:227-30.

12. Ching CK, Wong BC, Kwok E, Ong L, Covacci A, Lam SK. Prevalence of CagA-bearing Helicobacter pylori strains detected by the anti-CagA assay in patients with peptic ulcer disease and in controls. Am J Gastroenterol 1996;91:949-53.

13. Cover TL, Glupczynski Y, Lage AP, et al. Serologic detection of infection with cagA+ Helicobacter pylori strains. J Clin Microbiol 1995;33:1496-500.

14. Maeda S, Kanai F, Ogura K, et al. High seropositivity of anti-CagA antibody in Helicobacter pylori-infected patients irrelevant to peptic ulcers and normal mucosa in Japan. Dig Dis Sci 1997;42:1841-7.

15. Maeda S, Ogura K, Yoshida H, et al. Major virulence factors, vacA and cagA are commonly positive in Helicobacter pylori isolates in Japan. Gut 1998:42:338-43.

16. Park SM, Park J, Kim JG, et al. Infection with Helicobacter pylori expressing the cagA gene is not associated with an increased risk of developing peptic ulcer disease in Korean patients. Scand J Gastroenterol 1998;33:923-7.

17. Busolo F, Bertollo G, Bordignon G, Madia D, Camposampiero D. Detection and characterization of Helicobacter pylori from patients with gastroduodenal diseases. Diagn Microbiol Infect Dis 1998;31:531-6.

18. Holtmann G, Talley NJ, Mitchell H, Hazell S. Antibody response to specific $\mathrm{H}$ pylori antigens in functional dyspepsia, duodenal ulcer disease, and health. Am J Gastroenterol 1998;93:1222-7.

19. Miehlke S, Go MF, Kim JG, Graham DY, Figura N. Serologic detection of Helicobacter pylori infection with cagA-positive strains in duodenal ulcer, gastric cancer, and asymptomatic gastritis. J Gastroenterol 1998;33:18-21.

20. Megraud F. Advantages and disadvantages of current diagnostic tests for the detection of Helicobacter pylori. Scand J Gastroenterol 1996;31:57-62. 
21. Nilsson I, Ljungh A, Aleljung P, Wadstrom T. Immunoblot assay for serodiagnosis of Helicobacter pylori infections. J Clin Microbiol 1997;35:427-32.

22. Laheij RJ, Witteman EM, Bloembergen P, de Koning RW, Jansen JB, Verbeek AL. Short-term follow-up by serology of patients given antibiotic treatment for Helicobacter pylori infection. J Clin Microbiol 1998;36:1193-6.

23. Rocha G, Oliveira A, Quiroez D, Carvalho ST, Nogueira MM. Immunoblot analysis of humoral immune response to Helicobacter pylori in children with and without duodenal ulcers. J Clin Microbiol 2000;38:1777-81.

24. Figueiredo C, Quint W, Nouhan N, et al. Assessment of Helicobacter pylori vacA and cagA genotypes and host serological response. J Clin Microbiol 2001;39:1339-44.

25. Laheij RJ, Straatman H, Jansen JB, Verbeek AL. Evaluation of commercially available Helicobacter pylori serology kits: a review. J Clin Microbiol 1998;36:2803-9.

26. Parsonnet J. The incidence of Helicobacter pylori infection. Aliment Pharmacol 1995;9(Suppl 2):45-51.
27. Alarcon T, Martinez MJ, Urruzuno P, et al. Prevalence of CagA and VacA antibodies in children with Helicobacter pyloriassociated peptic ulcer compared to prevalence in pediatric patients with active or nonactive chronic gastritis. Clin Diagn Lab Immunol 2000;7:842-4.

28. Vaucher C, Janvier B, Nousbaum J-B, et al. Antibody response of patients with Helicobacter pylori-related gastric adenocarcinoma: significance of anti-CagA antibodies. Clin Diag Lab Immunol 2000;7:463-7.

29. Hu PJ, Li YY, Zhou MH, et al. Helicobacter pylori associated with a high prevalence of duodenal ulcer disease and a low prevalence of gastric cancer in a developing nation. Gut 1995;36:198-202.

30. Perez-Perez GI, Bhat N, Gaensbauer J, et al. Country-specific constancy by age in $\mathrm{CagA}(+)$ proportion of Helicobacter pylori infection. Int J Cancer 1997;72:453-6.

31. Mitchell HM, Hazell SL, Bohane TD Hu P, Chen M, Li YY. The prevalence of antibody to CagA in children is not a marker for specific disease. J Pediatr Gastroenterol Nutr 1999;28:71-5. 


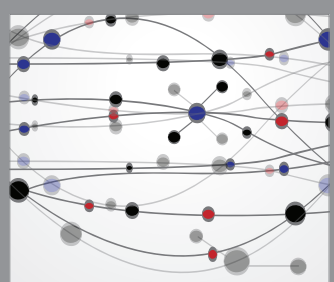

The Scientific World Journal
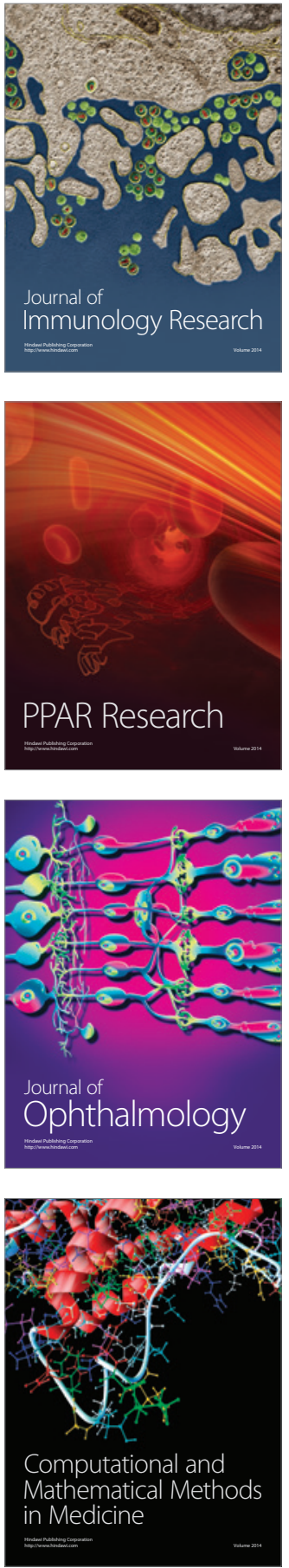

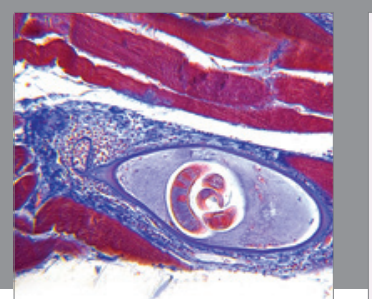

Gastroenterology Research and Practice

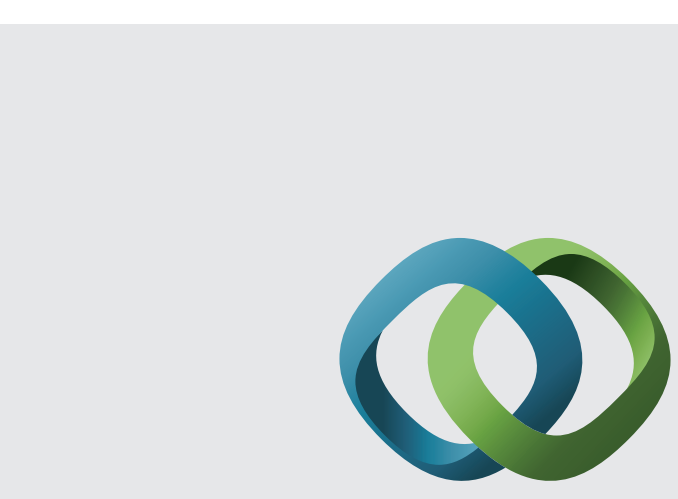

\section{Hindawi}

Submit your manuscripts at

http://www.hindawi.com
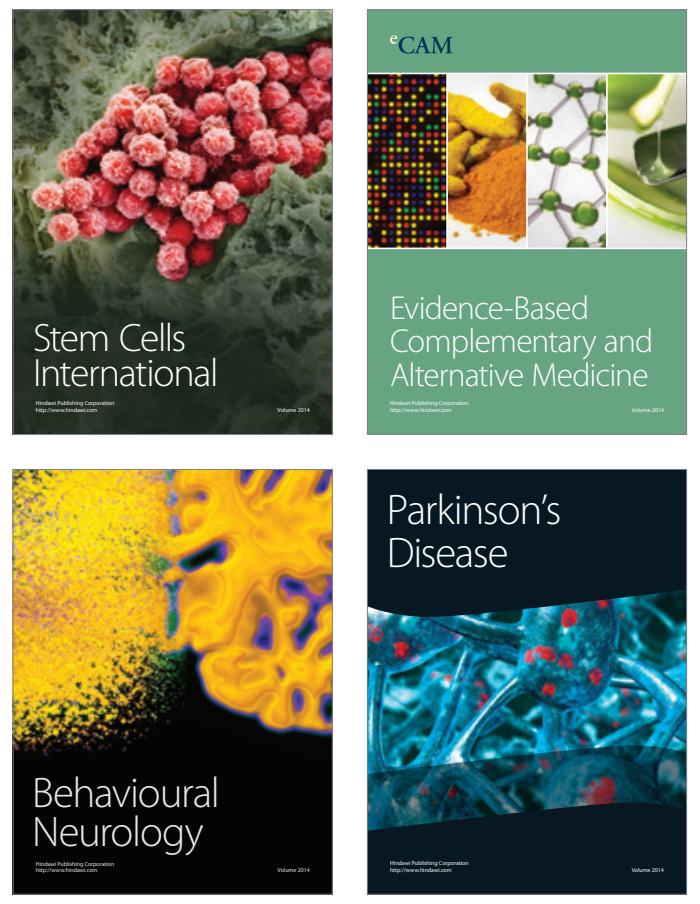
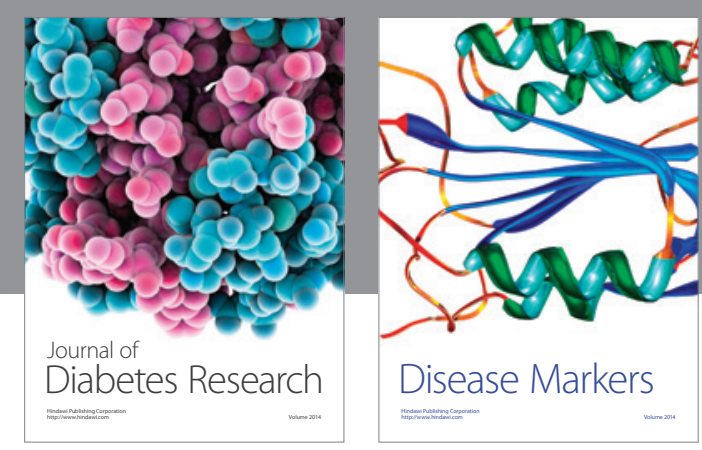

Disease Markers
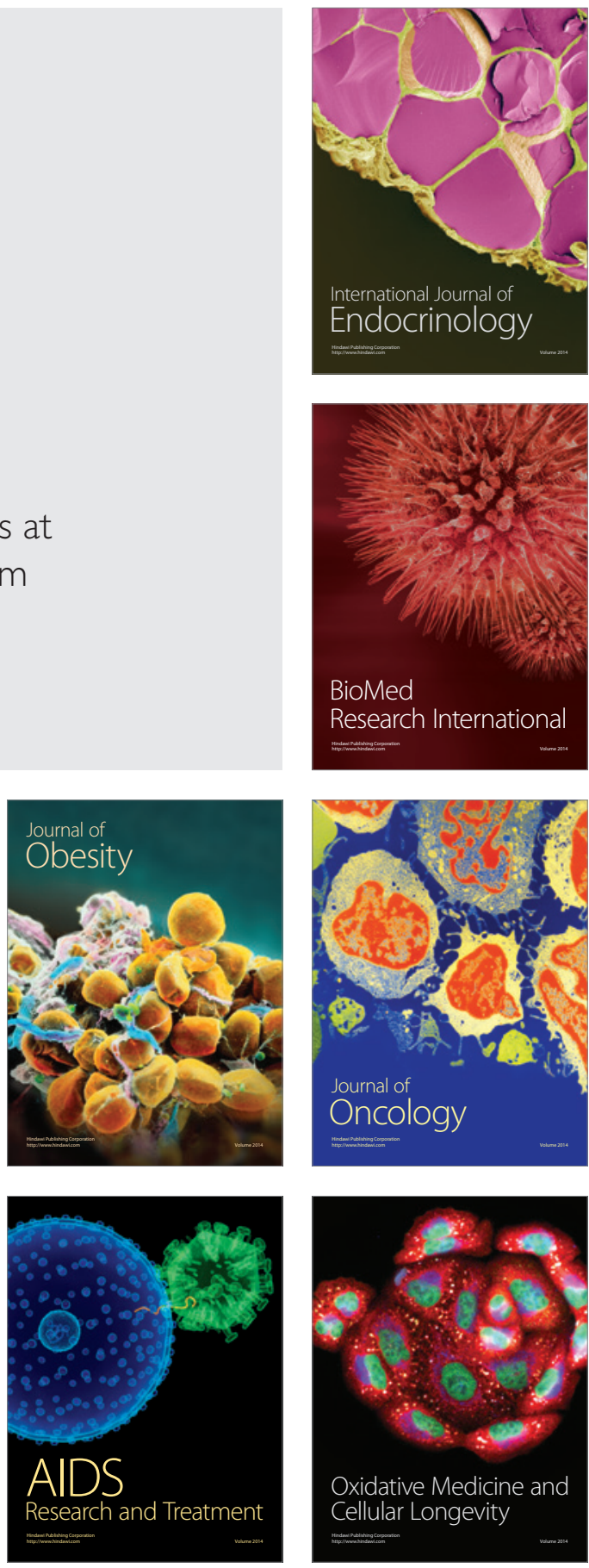